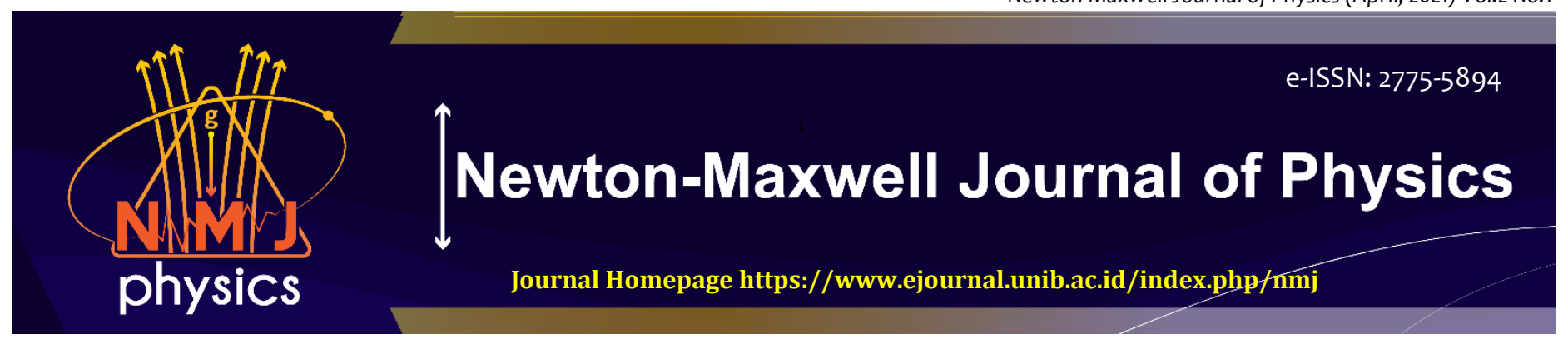

\title{
SEBARAN KUALITAS AIR LAUT DI PERAIRAN SEKITAR PLTU TELUK SEPANG KOTA BENGKULU BERDASARKAN PARAMETER FISIKA-KIMIA
}

\author{
Lizalidiawati ${ }^{*}$, Erma Juniarti, Budi Harlianto \\ Jurusan Fisika FMIPA Universitas Bengkulu, Bengkulu
}

\section{ARTICLE INFO}

\section{Riwayat Artikel:}

Draft diterima: 31 Maret 2021

Revisi diterima: 27 April 2021

Diterima: 28 April 2021

Tersedia Online: 29 April 2021

*Corresponding author: lizalidiawati@unib.ac.id

\begin{abstract}
ABSTRAK
PLTU Teluk Sepang Kota Bengkulu menghasilkan limbah bahang yang pembuangannya ke arah laut sehingga dapat mempengaruhi kualitas perairan tersebut dan dapat memberikan dampak negatif bagi kehidupan biota laut. Penelitian ini bertujuan untuk mengidentifikasi sebaran kualitas air laut di perairan sekitar PLTU Teluk Sepang Kota Bengkulu berdasarkan parameter fisika dan kimia. Metode yang digunakan pada penelitian ini adalah pengukuran langsung yang dilakukan pada 12 titik pengukuran, yaitu 4 titik berada di sekitar daerah outlet dan 8 titik di daerah luar outlet (lepas pantai). Hasil pengukuran dibandingkan dengan baku mutu air laut untuk kehidupan biota laut berdasarkan Keputusan Menteri Lingkungan Hidup No 51 Tahun 2004 dan validasi dengan hasil analisis kualitas air laut sebelum PLTU beroperasi. Hasil dari penelitian ini menunjukkan beberapa parameter masih sesuai dengan baku mutu untuk kehidupan biota laut, yaitu dissolve oxygen (DO) sebesar 5,62-7,82, $\mathrm{pH}$ dan kekeruhan di daerah lepas pantai dengan nilai masing-masing sebesar 7,24-7,86 dan 1,68-4,84 NTU. Sedangkan kondisi parameter yang tidak sesuai dengan baku mutu air laut adalah suhu air laut sebesar $30,6-36^{\circ} \mathrm{C}$, salinitas sebesar 26,6-30\%, $\mathrm{pH}$ dan kekeruhan di daerah outlet dengan nilai masing-masing sebesar 6,7-6,88 dan 23,25-146,8 NTU. Berdasarkan hasil validasi menunjukkan bahwa limbah bahang memberikan pengaruh yang sangat signifikan terhadap parameter fisika dan kimia perairan terutama suhu, $\mathrm{pH}$, dan kekeruhan.
\end{abstract}

Kata kunci: Limbah Bahang, pH air laut, Kualitas air, PLTU Teluk Sepang.

\section{ABSTRACT}

PLTU Teluk Sepang Bengkulu City produces heat waste dumped back into the sea which affects the quality of the water so that it has a negative impact on marine life. This study aimed to identify the quality of the water around PLTU Teluk Sepang Bengkulu City based on the physical and chemical parameters. The method used was direct measurement at the research location which is carried out at 12 measurement points, i.e 4 points around the outlet area, and 8 points in the off-shore area. The measurement result was compared with seawater quality standard for marine biota based on the Minister of Environment Decree No. 51 of 2004 and was validated by analysis of sea water quality before the PLTU had operated. The result showed that some parameters met the quality standards for marine biota included DO of 5.62-7.82, $\mathrm{pH}$ and turbidity in the offshore area with each value of 7.24-7.86 and 1.68-4.846 NTU. Meanwhile, the parameters which did not meet quality standards include a temperature of $30.62-36^{\circ} \mathrm{C}$, a salinity of $26.6-30 \%$, $\mathrm{pH}$ and turbidity around the outlet area with each value of 6.7-6.88 and 23.25-146.8 NTU. Based on the validation result, it showed that heat waste had a very significant effect on the physical and chemical parameters of the waters, especially on temperature, $\mathrm{pH}$, and turbidity.

Keywords: Heat Waste, seawater PH, Water Quality, PLTU Teluk Sepang.

\section{PENDAHULUAN}

Pembangkit Listrik Tenaga Uap (PLTU) merupakan pembangkit listrik yang menggunakan tenaga uap untuk menggerakkan turbin sehingga dapat menghasilkan tenaga listrik. PLTU bekerja dengan menggunakan air yang dipanaskan. Faktanya bahwa air 
Lizalidiawati, dkk. Sebaran Kualitas Air Laut Di Perairan Sekitar PLTU Teluk Sepang Kota Bengkulu Berdasarkan Parameter FisikaKimia

membutuhkan biaya yang rendah, mudah didapatkan dan merupakan media yang efektif untuk digunakan sebagai penukar panas [1]. Pembangunan PLTU yang berada di Provinsi Bengkulu tepatnya terletak di Kelurahan Teluk Sepang Kecamatan Kampung Melayu Kota Bengkulu, dengan kapasitas listrik sebesar 2x100 Mega Watt (MW) yang dibangun di atas lahan seluas 35 hektar oleh PT. Intraco Penta (INTA) yang berkerjasama dengan Power Construction of China (PCCC group). Pembangunan PLTU Teluk Sepang Kota Bengkulu ini menggunakan sistem pendingin siklus terbuka di mana air laut dipasok secara kontinu dan dialirkan ke kondensor sehingga menghasilkan limbah bahang dengan suhu yang lebih tinggi dari suhu air laut yang akhirnya dibuang kembali ke laut melalui saluran outlet.

Limbah bahang yang keluar dari saluran outlet ke laut akan dibawa oleh arus sehingga bercampur dan menyebar ke perairan laut di sekitar PLTU. Menurut [2] arus memiliki peranan penting dalam menentukan kondisi suatu perairan di mana kecepatan dan arah serta pola pergerakan arus laut dapat membawa material-material serta sifat-sifat yang terdapat dalam badan air. Proses fisis yang paling mendasar dalam transformasi panas adalah ketika limbah panas masuk ke dalam badan air, hal ini menyebabkan suhu air meningkat sehingga terjadi kehilangan keseimbangan panas di permukaan [3]. Masuknya limbah bahang dari saluran outlet ke laut (thermal pollution) dalam jumlah besar dapat memberikan dampak negatif bagi kehidupan biota laut. Menurut [4] masuknya limbah secara terus menerus ke perairan dapat menyebabkan pengaruh negatif karena akan menyebabkan pemekatan dan akumulasi di dalam ekosistem perairan. Biota laut dapat hidup, tumbuh dan berkembang dalam batas-batas suhu tertentu. Perubahan suhu tersebut kemungkinan juga dapat mempengaruhi salinitas karena adanya proses percampuran antara air limbah dengan air di sekitarnya [5].

Menurut [6] pembuangan limbah bahang dengan suhu yang lebih tinggi dari suhu air laut dapat menurunkan kadar Dissolved Oxygen (DO) air laut. Menurunnya kadar DO di suatu perairan dapat menyebabkan terganggunya ekosistem perairan sehingga mengakibatkan semakin berkurangnya populasi biota. Menurut [7] kondisi DO dalam perairan berkaitan langsung dengan pH air di mana saat $\mathrm{DO}$ rendah maka $\mathrm{pH}$ air akan menjadi asam. $\mathrm{pH}$ air laut yang bertambah asam akan mempengaruhi populasi global fitoplankton dan mikroorganisme di permukaan laut yang membentuk dasar rantai makanan di laut serta dapat menyebabkan kematian biota laut. Menurut [8] arus laut, suhu, salinitas, pH, DO, dan kekeruhan merupakan parameter fisika dan kimia perairan yang dapat menentukan kualitas suatu perairan. Beberapa penelitian yang dilakukan untuk membuktikan bahwa pembuangan limbah bahang dengan suhu yang lebih tinggi dari suhu air laut akan mengakibatkan peningkatan suhu air laut secara permanen. Penelitian yang dilakukan oleh [9] menunjukkan bahwa suhu permukaan laut yang dipengaruhi oleh limbah bahang dari PLTU Tanjung Jati B Jepara dengan jarak penyebaran 4.709 meter dan suhu maksimal mencapai $34,5^{\circ} \mathrm{C}$. Kemudian nmembuktikan bahwa sejak PLTU Jeneponto beroperasi suhu air laut yang awalnya berkisar antara $28^{\circ} \mathrm{C}-29^{\circ} \mathrm{C}$ meningkat menjadi $29,7^{\circ} \mathrm{C}-33,4{ }^{\circ} \mathrm{C}$ akibat pembuangan limbah bahang. Selain peningkatan suhu air laut, pembuangan limbah bahang PLTU Jeneponto juga mengakibatkan perairan di sekitar wilayah pengoperasian PLTU masuk dalam kategori pencemaran sedang atau cukup berat sampai kategori pencemaran berat, yang ditunjukkan dengan menurunnya jumlah spesies dan keanekaragaman plankton. Berdasarkan penelitian yang telah dilakukan dan menurut Organisasi Lingkungan Kanopi Bengkulu setelah PLTU uji coba, limbah cair yang keluar dari saluran outlet berbuih berwarna kecoklatan dan berbau menyengat serta banyak biota laut mati di sekitar perairan. Oleh karena itu sangat perlu dilakukan penelitian ini. Parameter fisika yang diambil hanya arus laut, suhu, salinitas, dan kekeruhan. Sedangkan parameter kimia hanya $\mathrm{pH}$ dan, DO.

\section{TUJUAN}

Penelitian ini bertujuan untuk mengidentifikasi sebaran kualitas air laut di perairan sekitar PLTU Teluk Sepang Kota Bengkulu berdasarkan parameter fisika dan kimia.

\section{METODE PENELITIAN}

Penelitian ini dilakukan di sekitar pembuangan limbah PLTU Bengkulu di Kelurahan Teluk Sepang Kecamatan Kampung Melayu Kota Bengkulu. Pengambilan data dilakukan pada 12 titik pengukuran seperti pada Gambar 1. Pengambilan data di lapangan dilaksanakan pada bulan Januari dan Maret 2020.

Data yang digunakan merupakan data sekunder dan primer. Data sekunder berupa hasil analisis kualitas air laut sebelum PLTU beroperasi pada bulan April tahun 2017. Sedangkan data primer berupa data pengukuran secara in-situ yaitu pada saat 3 bulan setelah tahap pertama PLTU uji coba (Januari) dan setelah PLTU beroperasi tetapi belum secara komersial (Maret). Pengukuran parameter fisika dan kimia diambil pada 12 titik stasiun, yaitu 8 titik diambil di lepas pantai untuk mewakili daerah yang menjauhi outlet, sedangkan 4 titik diambil di daerah outlet untuk melihat sebaran limbah bahang PLTU Teluk Sepang Kota Bengkulu. Pengukuran kecepatan arus dan suhu dilakukan dengan menggunakan current meter. Pengukuran arah arus dilakukan dengan menggunakan drifter. Pengukuran salinitas dilakukan dengan menggunakan Refractometer 0 10\%. Pengukuran pH 
dilakukan dengan menggunakan pH meter. Pengukuran DO dilakukan dengan menggunakan alat DO meter. Kemudian pengukuran kekeruhan air laut dilakukan dengan menggunakan alat turbidity meter TU2016

Analisis data dilakukan secara deskriptif yaitu untuk mendapatkan gambaran tentang sebaran kondisi parameter fisika dan kimia air laut di perairan tersebut. Hasil pengukuran dibandingkan dengan baku mutu kualitas air laut untuk biota laut berdas arkan Keputusan Menteri Lingkungan Hidup Nomor 51 Tahun 2004 (KepMenLH No. 51, 2004) untuk mengetahui kualitas air laut di perairan Teluk Sepang. Kemudian dilakukan juga validasi hasil pengukuran dengan hasil pengukuran kualitas air laut pada bulan April tahun 2017 sebelum PLTU beroperasi.

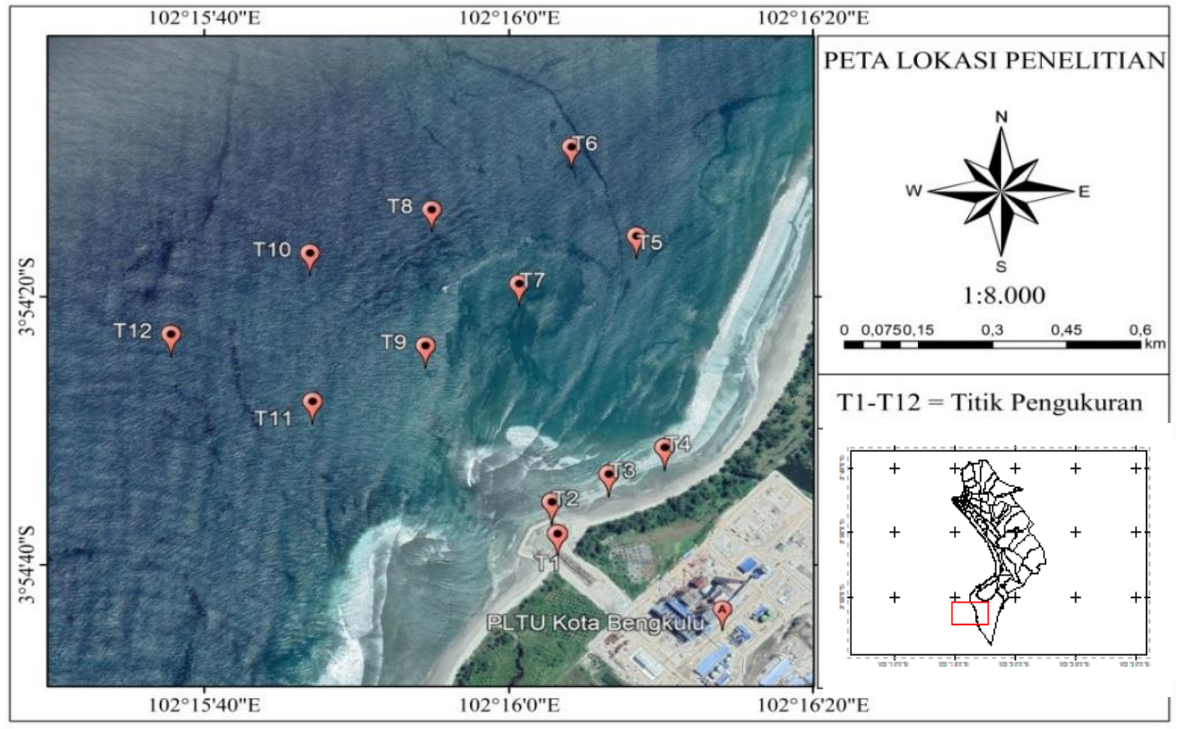

Gambar 1. Peta lokasi penelitian (Sumber Google Earth 2019)

\section{HASIL DAN PEMBAHASAN}

\section{a. Arus Laut}

Pergerakan arus laut akan membawa material-material yang terdapat dalam badan air sehingga akan berpindah dari suatu tempat ke tempat lain. Hasil kecepatan arus pada saat 3 bulan setelah tahap pertama PLTU uji coba (Januari) Gambar $2 a$ menunjukkan nilai yang bervariasi dengan kisaran rata-rata antara $0,12 \mathrm{~m} / \mathrm{s}-0,56 \mathrm{~m} / \mathrm{s}$ dengan nilai tertinggi terletak pada titik pengukuran T1 dan terendah pada titik pengukuran T10. Hasil kecepatan arus setelah PLTU beroperasi (Maret) Gambar 2b menunjukkan nilai yang relatif konstan pada titik pengukuran T5-T12, kecepatan arus pada bulan Maret berkisar antara 0,06 m/s - 0,7 m/s dengan nilai tertinggi berada pada titik pengukuran T1 dan terendah berada pada titik pengukuran T7. Besarnya kecepatan arus (Gambar 2) pada titik pengukuran T1 disebabkan oleh angin dan banyaknya volume air limbah yang keluar dari saluran outlet. Sedangkan untuk arah arus menunjukkan arus bergerak ke arah Timur menuju ke perairan Kota Bengkulu.

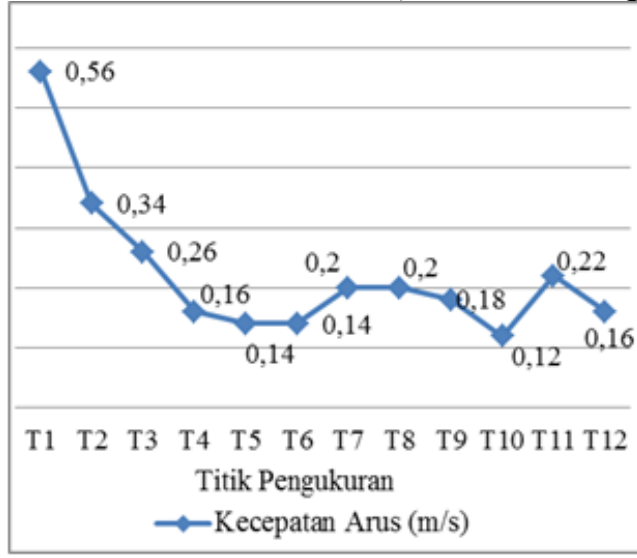

(a)

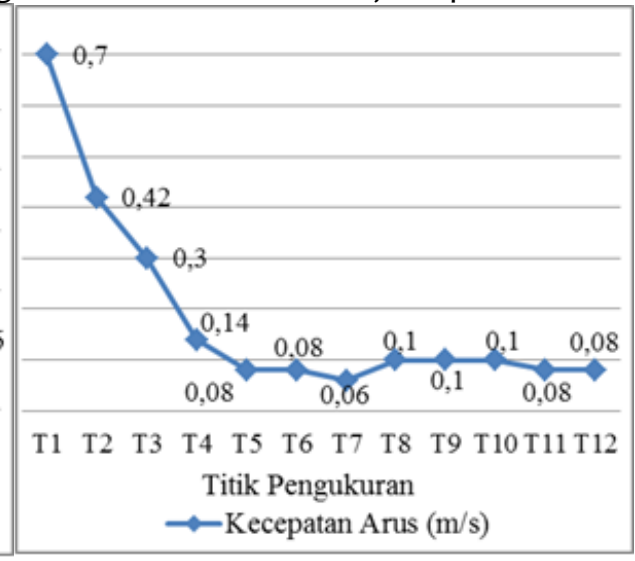

(b)

Gambar 2. (a) Grafik kecepatan arus laut pada saat 3 bulan setelah tahap pertama PLTU uji coba (Januari) dan (b) Grafik kecepatan arus laut setelah PLTU beroperasi (Maret) 
Lizalidiawati, dkk. Sebaran Kualitas Air Laut Di Perairan Sekitar PLTU Teluk Sepang Kota Bengkulu Berdasarkan Parameter FisikaKimia

\section{b. Kualitas Air Laut}

Tabel 1 Data rata- rata suhu, salinitas, pH, DO, dan kekeruhan pada saat 3 bulan setelah tahap pertama PLTU uji coba (Januari 2020) serta baku mutu air laut untuk biota laut (KepMenLH No. 51, 2004) dan hasil analisis kualitas air laut sebelum PLTU beroperasi pada bulan April tahun 2017

\begin{tabular}{|c|c|c|c|c|c|c|c|c|c|c|c|c|c|c|}
\hline Parameter & $\begin{array}{l}\text { Baku mutu air laut } \\
\text { untuk biota laut } \\
(\text { KepMenLH 2004) }\end{array}$ & T1 & $\mathrm{T} 2$ & T3 & T4 & T5 & T6 & T7 & T8 & T9 & T10 & T11 & T12 & To \\
\hline Suhu $\left({ }^{\circ} \mathrm{C}\right)$ & $28-30$ & 32,44 & 30,46 & 30,4 & 30,16 & 29,72 & 29,76 & 29,74 & 29,6 & 29,9 & 30,1 & 30,5 & 30,1 & 28,7 \\
\hline Salinitas (\%) & $33-34$ & 28,8 & 30 & 30 & 30 & 30,2 & 30,2 & 30,2 & 30,6 & 30,6 & 30,8 & 30 & 30,8 & - \\
\hline $\mathrm{Ph}$ & $7-8,5$ & 6,76 & 6,8 & 7,14 & 7,14 & 7,38 & 7,48 & 7,64 & 7,78 & 7,9 & 7,86 & 7,92 & 7,9 & 7,6 \\
\hline $\mathrm{DO}(\mathrm{mg} / \mathrm{L})$ & $>5$ & 6,5 & 6,76 & 6,78 & 6,84 & 7 & 8,06 & 8,02 & 6,92 & 6.98 & 6,94 & 7,02 & 7,7 & 11,4 \\
\hline Kekeruhan (NTU) & $<5$ & 5,29 & 3,1 & 2,34 & 1,59 & 0,99 & 0.92 & 0,97 & 3,46 & 2,9 & 0,94 & 5,42 & 0,97 & 4 \\
\hline
\end{tabular}

Tabel 2 Data rata- rata suhu, salinitas, pH, DO, dan kekeruhan setelah PLTU beroperasi (Maret 2020) serta baku mutu air laut untuk biota laut (KepMenLH No. 51, 2004) dan hasil analisis kualitas air laut sebelum PLTU beroperasi pada bulan April tahun 2017

\begin{tabular}{|c|c|c|c|c|c|c|c|c|c|c|c|c|c|c|}
\hline Parameter & $\begin{array}{l}\text { Baku mutu air laut } \\
\text { untuk biota laut } \\
\text { (KepMenLH 2004) }\end{array}$ & T1 & $\mathrm{T} 2$ & T3 & T4 & T5 & T6 & T7 & T8 & T9 & T10 & T11 & T12 & To \\
\hline Suhu $\left({ }^{\circ} \mathrm{C}\right)$ & $28-30$ & 36 & 35,34 & 35,26 & 35,2 & 30,8 & 30,7 & 30,76 & 30,62 & 30,66 & 30,62 & 30,68 & 30,64 & 28,7 \\
\hline Salinitas (\%) & $33-34$ & 26,6 & 28,4 & 28,6 & 29 & 29,6 & 29,8 & 30 & 30 & 30 & 30 & 30 & 30 & - \\
\hline $\mathrm{Ph}$ & $7-8,5$ & 6,7 & 6,78 & 6,88 & 6,88 & 7,32 & 7,24 & 7,42 & 7,38 & 7,62 & 7,46 & 7,54 & 7,86 & 7,6 \\
\hline $\mathrm{DO}(\mathrm{mg} / \mathrm{L})$ & $>5$ & 5,62 & 5,68 & 5,68 & 5,7 & 6,26 & 7,8 & 7,82 & 6,48 & 6,92 & 6,5 & 7,44 & 7,82 & 11,4 \\
\hline Kekeruhan (NTU) & $<5$ & 146,8 & 38,09 & 24,47 & 23,25 & 4,04 & 3,73 & 3,25 & 2,82 & 3,44 & 1,89 & 4,84 & 1,68 & 4 \\
\hline
\end{tabular}

Keterangan : T1-T12 : Titik pengukuran;

To : Hasil analisis kualitas air laut sebelum PLTU beroperasi pada bulan April tahun 2017.

\section{i. Suhu}

Hasil pengukuran suhu air laut yang dilakukan 3 bulan setelah PLTU uji coba diperoleh hasil yang cukup bervariasi yaitu, antara $29,6^{\circ} \mathrm{C}-32,4^{\circ} \mathrm{C}$ (Gambar 3a). jika dibandingkan dengan baku mutu air laut untuk kehidupan biota laut seperti ditunjukkan Tabel 1 , suhu air laut pada titik pengukuran $T_{5}$ sampai T 9 masih berada di antara kisaran baku mutu untuk kehidupan biota laut. Sedangkan data pada titik pengukuran $\mathrm{T} 1, \mathrm{~T} 2, \mathrm{~T} 3, \mathrm{~T} 4, \mathrm{~T} 10, \mathrm{~T} 11$ dan $\mathrm{T} 12$ tidak memenuhi standar baku mutu yaitu suhunya lebih dari $30^{\circ} \mathrm{C}$. $\mathrm{Hasil}$ Gambar 3b menunjukkan suhu air laut setelah PLTU beroperasi (Maret) pada setiap titik pengukuran, yaitu berkisar antara $30,6^{\circ} \mathrm{C}$ $-36^{\circ} \mathrm{C}$. Suhu cenderung tinggi pada titik pengukuran T1-T4 (di sekitar daerah outlet), yaitu sebesar $35,2^{\circ} \mathrm{C}-36,0^{\circ} \mathrm{C}$. Setelah lepas pantai pada titik pengukuran $\mathrm{T} 5-\mathrm{T} 12$ suhu air laut mengalami penurunan, yaitu sebesar $30,6^{\circ} \mathrm{C}-30,8^{\circ} \mathrm{C}$ dan jika dibandingkan dengan baku mutu air laut untuk kehidupan biota laut berdasarkan KepMenLH No. 51, 2004 seperti disajikan pada Tabel 2, data pada setiap titik pengukuran tidak memenuhi standar baku mutu air laut untuk kehidupan biota laut.

Berdasarkan hasil analisis kualitas air laut seperti disajikan pada Tabel 2 yang dilakukan di sekitar perairan PLTU sebelum PLTU beroperasi pada bulan April tahun 2017 suhu yang di dapat yaitu sebesar $28,7^{\circ} \mathrm{C}$ jika dibandingkan dengan hasil pengukuran (Gambar 3) pada saat 3 bulan setelah tahap pertama PLTU uji coba (Januari), suhu air laut meningkat menjadi $29,6{ }^{\circ} \mathrm{C}-32,4^{\circ} \mathrm{C}$, sedangkan jika dibandingkan dengan pengukuran setelah PLTU beroperasi (Maret) suhu air laut semakin meningkat yaitu sebesar $30,6^{\circ} \mathrm{C}-36,0^{\circ} \mathrm{C}$. Hal ini sesuai dengan penelitian yang telah dilakukan [10] yang menyatakan bahwa penurunan kualitas perairan disebabkan oleh adanya buangan air panas yang berdampak terhadap meningkatnya suhu perairan sekitar wilayah pembangkit listrik, dari data survei amdal dan penelitian suhu di perairan Punagaya dan sekitarnya suhu awal perairan sebelum PLTU 
beroperasi berkisar antara $28,0^{\circ} \mathrm{C}-29,0^{\circ} \mathrm{C}$ dan setelah PLTU beroperasi meningkat menjadi $29,7^{\circ} \mathrm{C}-33,4^{\circ} \mathrm{C}$. Hal ini membuktikan bahwa limbah bahang PLTU memberikan pengaruh yang besar terhadap perubahan suhu air laut.

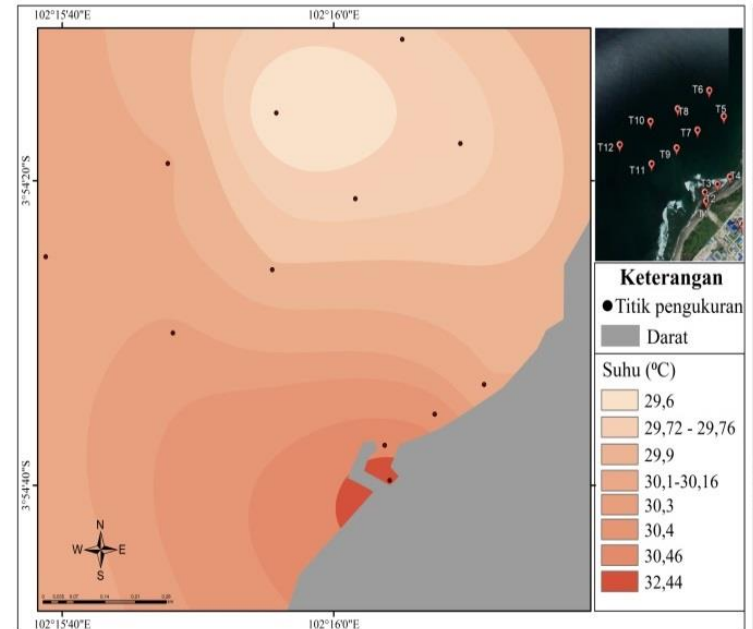

(a)

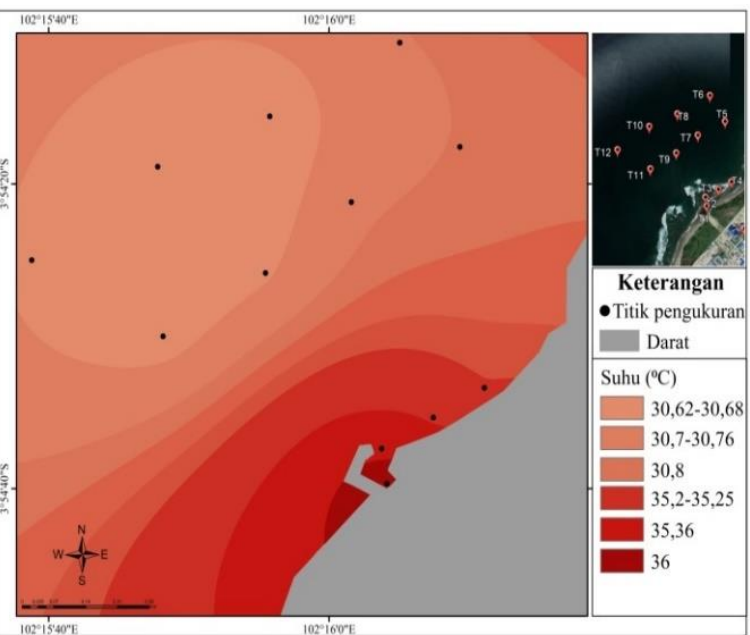

(b)

Gambar 3 (a) Peta sebaran suhu air laut pada saat 3 bulan setelah tahap pertama PLTU uji coba (Januari) dan (b) Peta sebaran suhu air laut setelah PLTU beroperasi (Maret)

\section{ii. Salinitas}

Pengukuran salinitas pada saat 3 bulan setelah tahap pertama PLTU uji coba (Januari) Gambar 4a pada setiap titik pengukuran menunjukkan kisaran antara $28,8 \%$ - 30,8\%. Nilai salinitas tertinggi terletak pada titik pengukuran T10 dan T12, yaitu $30,8 \%$ sedangkan nilai terendah terletak pada titik pengukuran T1, yaitu sebesar $28,8 \%$. Hasil pengukuran setelah PLTU beroperasi (Maret) Gambar 4b pada setiap titik pengukuran menunjukkan bahwa nilai salinitas berkisar antara $26,6 \%$ - $30 \%$ dengan nilai tertinggi terletak pada titik pengukuran T7- T12, yaitu 30 \% sedangkan nilai terendah terletak pada titik pengukuran T1, yaitu $26,6 \%$.

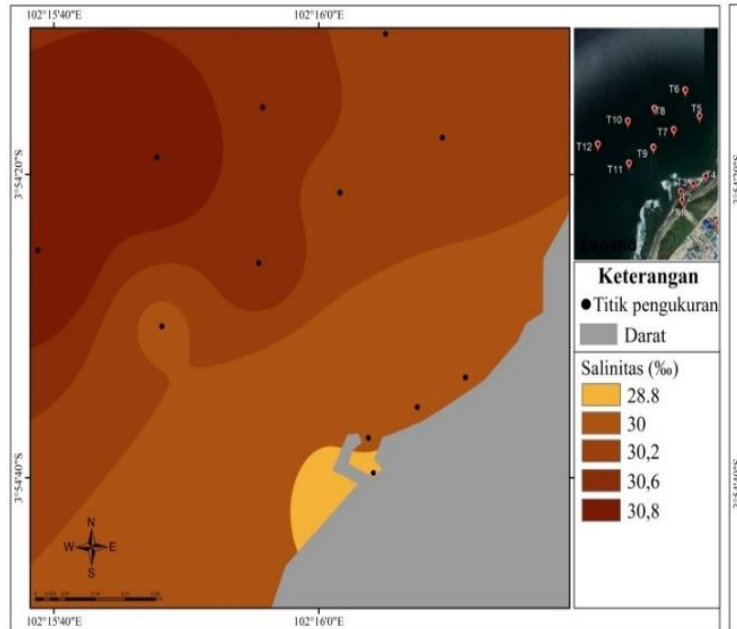

(a)

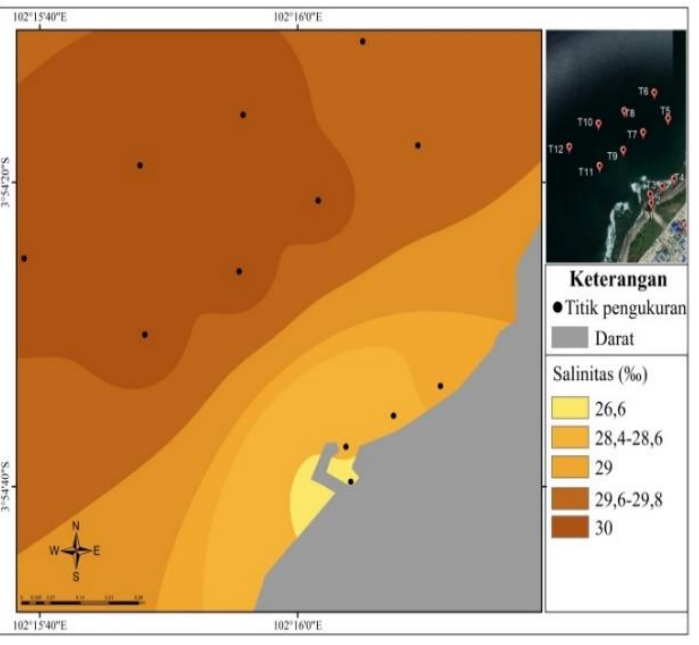

(b)

Gambar 4 (a) Peta sebaran salinitas pada saat 3 bulan setelah tahap pertama PLTU uji coba (Januari) dan (b) Peta sebaran salinitas setelah PLTU beroperasi (Maret).

Berdasarkan baku mutu air laut untuk kegiatan kehidupan biota laut seperti ditunjukkan pada Tabel 2, nilai salinitas untuk kehidupan biota laut berkisar antara 33\% - 34\%, secara umum nilai salinitas di sekitar perairan PLTU yang terukur tidak memenuhi standar baku mutu air sehingga akan berdampak pada kehidupan biota laut yang berada di sekitar perairan PLTU. Nilai salinitas yang diperoleh cenderung berbanding terbalik dengan nilai suhu. Kondisi ini sama dengan penelitian yang dilakukan oleh [11] bahwa semakin tinggi nilai salinitas maka akan semakin rendah nilai suhunya. Hasil perbandingan menunjukkan bahwa limbah bahang PLTU mempengaruhi nilai salinitas yang ditandai dengan menurunnya nilai salinitas yang cukup singnifikan pada titik 
Lizalidiawati, dkk. Sebaran Kualitas Air Laut Di Perairan Sekitar PLTU Teluk Sepang Kota Bengkulu Berdasarkan Parameter FisikaKimia

pengukuran T1 hingga T3, rendahnya nilai salinitas pada titik pengukuran tersebut dikarenakan adanya pencampuran antara dua massa air yang berbeda, yaitu air limbah dengan air laut selain itu tingginya nilai suhu juga mengakibatkan penurunan salinitas.

\section{iii. $\mathrm{pH}$}

Hasil pengukuran pH menunjukkan perbedaan yang tidak terlalu jauh antar titik pengukuran, yaitu berkisar antara 6,76-7,92 (Gambar 5a). Jika mengacu pada baku mutu pH yang telah diisyaratkan untuk menunjang kehidupan biota laut berdasarkan KepMenLH No. 51, 2004, pada saat 3 bulan setelah tahap pertama PLTU uji coba (Januari) nilai pH pada titik pengukuran T3-T12 masih memenuhi baku mutu yang telah ditetapkan, di mana nilai $\mathrm{pH}$ yang didapat $>7$ yang berarti parairan tersebut masih bersifat basa. Akan tetapi pada titik pengukuran T1 dan T2 sudah tidak memenuhi baku mutu karena pH yang di dapat $>7$ yang berarti air laut pada titik pengukuran tersebut telah bersifat asam. Sedangkan data hasil peta sebaran setelah PLTU beroperasi (Maret) Gambar $5 \mathrm{~b}$ menunjukkan nilai pH pada setiap titik pengukuran berkisar antara 6,7-7,86. Jika mengacu pada baku mutu nilai $\mathrm{pH}$ pada titik pengukuran T5-T12 masih memenuhi standar baku mutu yang telah ditetapkan, di mana kondisi airnnya masih bersifat basa. Akan tetapi pada titik pengukuran T1-T4 pH sudah tidak memenuhi standar baku mutu, di mana airnya cendung bersifat asam.

Berdasarkan hasil analisis kualitas air laut sebelum PLTU beroperasi pada bulan April tahun 2017 (Tabel 2) pH yang didapat yaitu sebesar 7,6 yang bersifat basa, jika dibandingkan dengan hasil pengukuran pada saat 3 bulan setelah tahap pertama PLTU uji coba (Januari) pH yang didapat sebesar 6,76-7,92 dan setelah PLTU beroperasi (Maret) pH air laut berubah menjadi 6,7-7,86. Data $\mathrm{pH}$ yang di dapat sebelum dan setelah PLTU beroperasi menunjukkan terjadinya peningkatan dan penurunan $\mathrm{pH}$ air laut. Penurunan $\mathrm{pH}$ cenderung terjadi pada titik pengukuran yang berada di sekitar daerah outlet (T1-T4) yang mengakibatkan sifat air berubah menjadi asam.

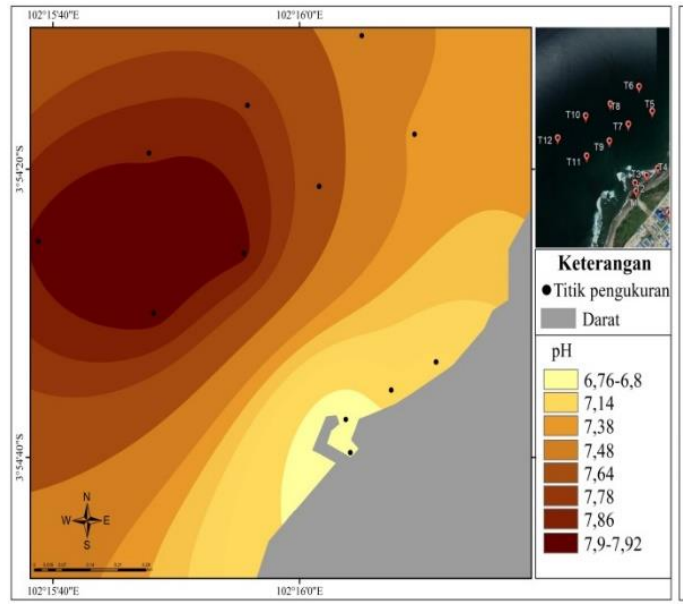

(a)

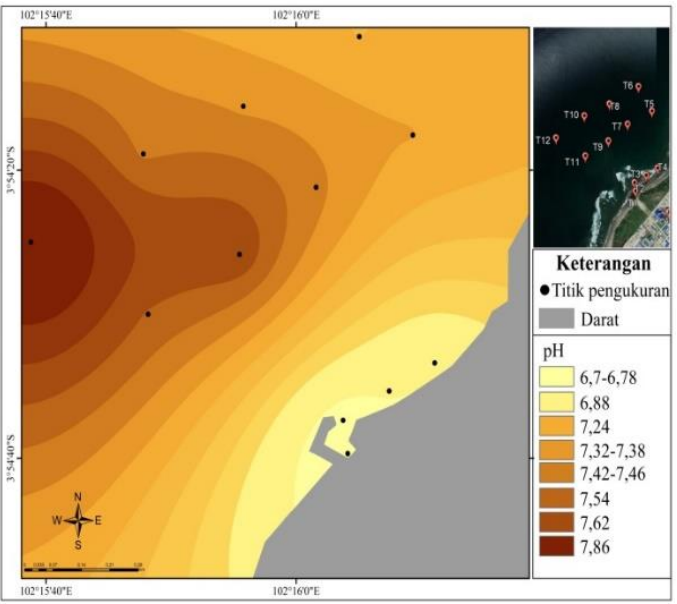

(b)

Gambar 5 (a) Peta sebaran pH air laut pada saat 3 bulan setelah tahap pertama PLTU uji coba (Januari) dan (b) Peta sebaran pH air laut setelah PLTU beroperasi (Maret)

\section{iv. $\quad$ Dissolved Oxygen (DO)}

Nilai DO yang terukur pada saat 3 bulan setelah tahap pertama PLTU uji coba (Januari) Gambar 6a, yaitu berkisar antara 6,5$8,06 \mathrm{mg} / \mathrm{L}$ dengan nilai DO tertinggi terletak pada titik pengukuran T6, yaitu sebesar 8,06 dan nilai yang terendah terletak pada titik pengukuran T1, yaitu sebesar 6,5 mg/L. Hasil pengukuran setelah PLTU beroperasi (Maret) Gambar 6b, menunjukkan nilai DO yang terukur berkisar antara 5,62-7,82 mg/L dengan nilai tertinggi terletak pada titik pengukuran T6, T7 dan T12, yaitu sebesar 7,82 $\mathrm{mg} / \mathrm{L}$ dan untuk nilai DO terendah terletak pada titik pengukuran T1, yaitu sebesar 5,62 mg/L. Jika mengacu pada baku mutu air laut untuk kehidupan biota laut bahwa DO yang baik yaitu lebih dari $5 \mathrm{mg} / \mathrm{L}$, data hasil pengukuran DO mengindikasikan bahwa perairan di sekitar PLTU berada pada kondisi DO yang baik karena pada setiap titik pengukuran memiliki nilai DO yang lebih besar dari 5 mg/L.Berdasarkan hasil analisis kualitas air laut sebelum PLTU beroperasi pada bulan April tahun 2017 (Tabel 2) nilai DO di sekitar perairan PLTU yaitu sebesar 11,4 mg/L, jika dibandingkan dengan hasil pengukuran pada saat 3 bulan setelah tahap pertama PLTU uji coba (Januari), DO mengalami penurunan secara signifikan menjadi 6,5-8,06 mg/L, sedangkan jika dibandingkan dengan pengukuran setelah PLTU beroperasi (Maret) DO semakin menurun menjadi 5,62-7,82 mg/l. 


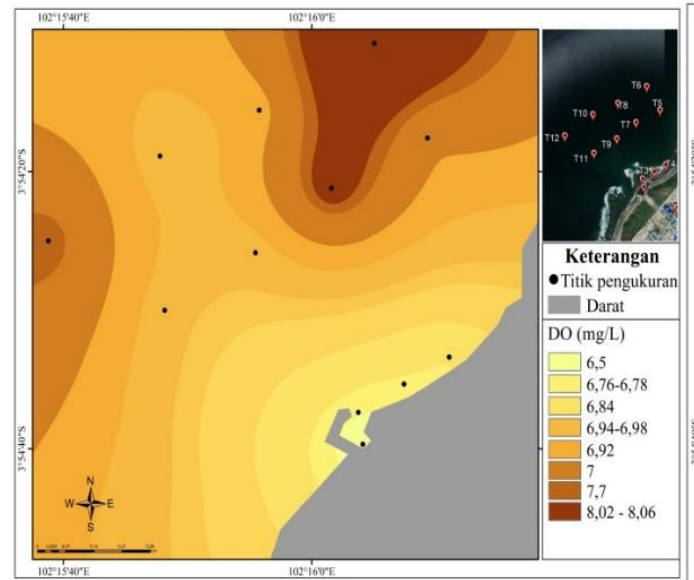

(a)

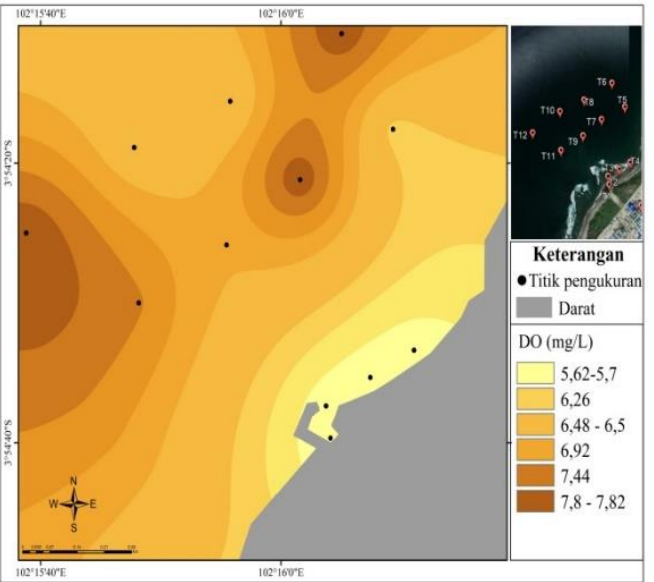

(b)

Gambar 6 (a) Peta sebaran DO pada saat 3 bulan setelah tahap pertama PLTU uji coba (Januari) dan (b) Peta sebaran DO setelah PLTU beroperasi (Maret).

\section{v. Kekeruhan}

Hasil pengukuran tingkat kekeruhan di sekitar Perairan PLTU yang dilakukan 3 bulan setelah PLTU uji coba (Gambar 7a) berkisar antara 0,92 NTU hingga 5,42 NTU. Nilai kekeruhan paling tinggi teramati pada titik pengukuran T1 dan T11 sebesar 5, 29 NTU dan 5,42 NTU yang berarti menunjukkan bahwa nilai kekeruhan pada titik pengukuran tersebut tidak sesuai untuk kehidupan biota laut, sedangkan pada titik pengukuran lainnya masih berada pada kondisi sesuai untuk kehidupan biota laut berdasarkan KepMenLH No. 51, 2004 (Tabel 1). Hasil pengukuran tingkat kekeruhan setelah PLTU beroperasi (Maret) Gambar 7b menunjukkan nilai kekeruhan yang terukur yaitu berkisar antara 1,68 NTU hingga 146,8 NTU dengan nilai tingkat kekeruhan tertinggi berada pada titik pengukuran T1, yaitu sebesar 146,8 NTU dan tingkat kekeruhan yang paling rendah terdapat pada titik pengukuran T10 dan T12, yaitu sebesar 1,89 NTU dan 1,68 NTU. Kondisi tingkat kekeruhan setelah PLTU beroperasi (Maret) menunjukkan bahwa pola sebaran kekeruhan cenderung menurun pada daerah lepas pantai. Hal ini mengindikasikan bahwa tingkat kekeruhan pada titik pengukuran T5-T12 cukup baik atau masih memenuhi baku mutu air laut untuk kehidupan biota laut seperti ditunjukkan pada Tabel 2 di mana tingkat kekeruhan tidak boleh lebih dari 5 NTU, akan tetapi pada titik pengukuran T1-T4 nilai kekeruhan yang didapat sangat tinggi sehingga melebihi batas ambang baku mutu yang dapat menyebabkan kehidupan biota laut terganggu. Berdasarkan hasil analisis kualitas air laut sebelum PLTU beroperasi pada bulan April tahun 2017 (Tabel 2) tingkat kekeruhan yang diperoleh di sekitar perairan PTLU yaitu sebesar 4 NTU jika dibandingkan dengan hasil pengukuran pada saat 3 bulan setelah tahap pertama PLTU uji coba (Januari), nilai kekeruhan meningkat pada titik pengukuran T1 dan T11 yaitu sebesar 5,29-5,42 NTU, sedangkan jika dibandingkan dengan pengukuran setelah PLTU beroperasi (Maret) nilai kekeruhan meningkat sangat signifikan pada titik pengukuran T1-T4 yaitu sebesar 23,25-146,8 NTU.

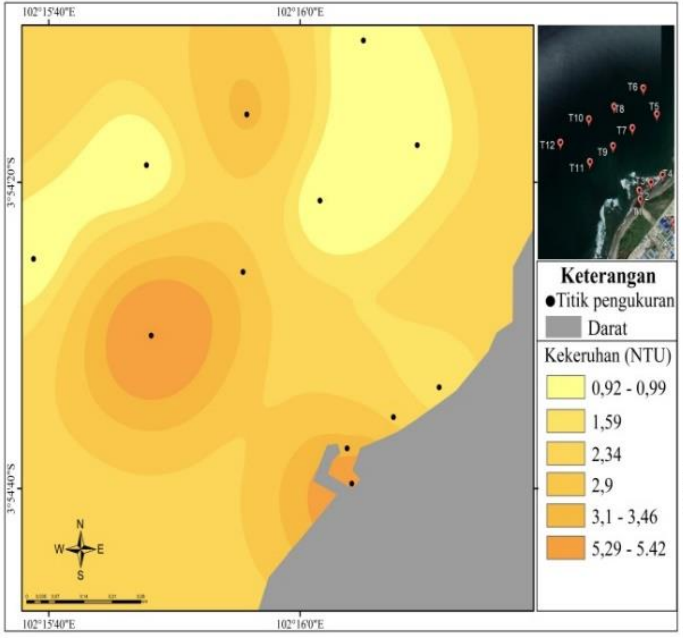

(a)

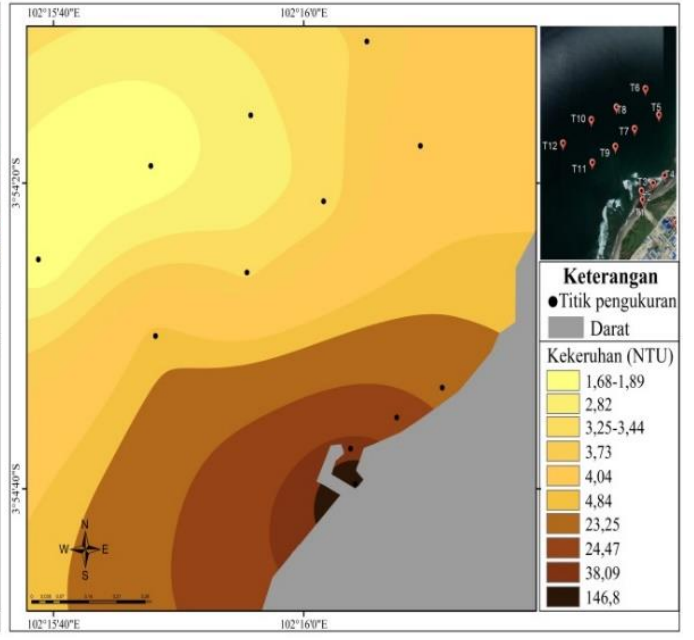

(b)

Gambar 7 (a) Peta sebaran kekeruhan pada saat 3 bulan setelah tahap pertama PLTU uji coba (Januari) dan (b) Peta sebaran kekeruhan setelah PLTU beroperasi (Maret) 
Lizalidiawati, dkk. Sebaran Kualitas Air Laut Di Perairan Sekitar PLTU Teluk Sepang Kota Bengkulu Berdasarkan Parameter FisikaKimia

\section{KESIMPULAN}

Berdasarkan hasil penelitian terlihat pola sebaran kondisi parameter yang masih sesuai dengan baku mutu untuk kehidupan biota laut berdasarkan KepMenLH No. 51, 2004, antara lain DO sebesar 5,62-7,82, pH dan kekeruhan yang berada di daerah lepas pantai dengan nilai masing-masing sebesar 7,24-7,86 yang bersifat basa dan 1,68-4,84 NTU. Sedangkan kondisi parameter air yang tidak sesuai dengan baku mutu antara lain suhu sebesar $30,62-36{ }^{\circ} \mathrm{C}$, salinitas $26,6-30 \%$, pH dan kekeruhan yang berada di sekitar daerah outlet dengan nilai masing-masing sebesar 6,7-6,88 yang bersifat asam dan 23,25-146,8 NTU. Hasil validasi data pengukuran dengan hasil analisis kualitas air laut sebelum PLTU beroperasi menunjukkan bahwa limbah bahang memberikan pengaruh yang sangat signifikan terhadap kondisi parameter fisika dan kimia terutama suhu, DO, dan kekeruhan yang dominan berada di sejajar pantai. Sehingga kualitas air di sekitar perairan tersebut menurun/terganggu.

\section{UCAPAN TERIMAKASIH}

Ucapan terima kasih diberikan kepada laboratorium Kelautan Jurusan Fisika FMIPA Universitas Bengkulu dan kepada semua pihak yang telah mendukung dan memfasilitasi penelitian ini.

\section{REFERENSI}

[1] M. Hutomo dan O.H. Arinardi, “Dampak Pembangkit Tenaga Listrik (Terutama Limbah Termal) Terhadap Ekosistem Akuatik", pp.135-158, 1992.

[2] S. Hadi dan I. Radjawane, "Arus Laut”, 2009.

[3] Y.M. Yustiani, S. Wahyuni, dan N.A. Wahyuni, "Pemodelan Matematis Sebaran Buangan Panas Cair dari Proses Pendinginan Pembangkit Listrik Tenaga Uap Banten Labuan”, Jurnal FT-UNPAS. 17(1): 15-24, 2015.

[4] S. Anggoro, "Pengelolaan dan Pemantauan Pencemaran dan Kerusakan Laut", 2011.

[5] A. Nontji, "Plankton Laut", 2008.

[6] M.A. Rosen, C.A. Bulucea, N.E. Mastorakis, C.A. Bulucea, A.C. Jeles, and C.C. Brindusa, "Evaluating the Thermal Pollution Caused by Wastewaters Discharged from A Chain Of Coal-Fired Power Plants Along A River", pp.5920-5943, 2015.

[7] T. Susana, "Tingkat Keasaman ( $\mathrm{pH}$ ) dan Oksigen Terlarut Sebagai Indikator Kualitas Perairan Sekitar Muara Sungai Cisadane", pp.33-39, 2009.

[8] D. Salim, Y. Yuliyanto, dan B. Baharuddin, "Karakteristik Parameter Oseanografi Fisika-Kimia Perairan Pulau Kerumputan Kabupaten Kotabaru Kalimantan Selatan”, pp.218-228, 2017.

[9] B.R.D. Angga, B. Rochaddi, dan A. Satriadi, "Analisa Sebaran Suhu Permukaan Laut Akibat Air Bahang PLTU Tanjung Jati B di Perairan Jepara", pp.393-399, 2015.

[10] H. Hafid, "Pengaruh Sebaran Suhu Air Pendingin PLTU Jeneponto terhadap Komunitas Plankton di Perairan Punagaya, Jeneponto-Sulsel", pp.97-102, 2015.

[11] P.A. Jumiarti dan D. Apdillah, "Pola Sebaran Salinitas dan Suhu di Perairan Teluk Riau Kota Tanjung Pinang Provinsi Kepulauan Riau", 2014. 